\title{
Analyze The Factors of Organizational Citizenship Behavior on Starbucks' Manager in Surabaya
}

\author{
Hellen Windiawatty Andahara Basary, Bayu Airlangga Saputra \\ Universitas Narotama, Surabaya, Indonesia \\ andahara.basary@gmail.com, bayu.airlangga71@gmail.com
}

\begin{abstract}
The objective of this study is to examine the influence of factors on OCB on Starbucks' Managers in Surabaya. The population is the managers of Starbucks Surabaya. Data collected by 30 questionnaires. Structural Equation Model (SEM) - PLS (Partial Least Square) has been employed to analyze the data. The results showed that 3 (three) hypotheses are accepted and 9 (nine) hypotheses are rejected. Five independent variables (employee development, employee communication, rewards and recognition, and leadership) had no significant effect on OCB with employee engagement as an intervening variable.
\end{abstract}

\section{Keywords :}

Intervening, OCB, PLS, SEM

\section{Introduction}

Successful organizations need employees who will do more than just their regular tasks, which will deliver performance exceeds expectations. Nowadays in the dynamic world of work, where tasks are increasingly being worked out in teams and flexibility is critical, organizations need employees who will demonstrate "good citizenship" behavior (Stephen P. Robbins, Tim Judge, Bruce Millett, 2014). Employees' effort to go beyond the formal and the extra role are the foundation for the concept of Organizational Citizenship Behavior (OCB).

Researchers make Starbucks the object of research. Starbucks has a CSR program in the form of social responsibility to society and the environment. Usually, employees of the OCB category are often found in companies or non-profit organizations. Meanwhile, Starbucks itself is a profit-oriented company that has an OCB program. This is what attracts researchers to analyze OCB factors.

The real dedication given by Starbucks employees becomes a basis for thinking and a point to analyze the factors possessed by employees that help them to act beyond the standard performance set and support the development of the company.

This research was conducted at the manager level of Starbucks employees. Because of the results of observations, the researcher shows an indication of high OCB in employees who are full-time employees at this level of position, which is more suitable to be the object of research when compared to employees with a status below the level.

\section{Literature Review}

\subsection{The relationship between Employee Development and Employee Engagement}

Organizations with a high level of employee engagement provide their employees with adequate opportunities to develop their abilities to acquire new knowledge and skills to take advantage of their potential in doing their jobs. (Mone et al., 2018) state that when managers provide opportunities for training and support the career development of an employee, the manager helps create employee development and employee engagement. (Kumar \& Swetha, 2011) suggest that an organization can increase engagement in its work environment by creating a learning culture and individual development plans for each employee because many studies state that most employees will remain interested in their work and have created if they acquire knowledge and skills. as well as using new approaches or methods every day in the world of work. The 2013 ASTD study suggested that employees want the opportunity to grow and have progressed in their organization and this has a direct impact on employee engagement, where $65 \%$ of respondents respond to the quality of opportunities to train and learn positively encouraging employee engagement at a higher level (Noviardila et al., 2020) (Muthuveloo et al., 2017). (C. Hoffman \& Paradise, 2008) states that training and development are important factors for increasing employee engagement. When employees undergo training and development programs for development, self-confidence is automatically built which will motivate employees to be more 
attached to their work. So if employees get several opportunities to grow and develop, the level of employee engagement is expected to increase later (J., 2014).

Hypothesis 1: There is a significant positive effect between Employee Development and Employee Engagement.

\subsection{The relationship between Employee Communication and Employee Engagement}

In employee engagement, communication between employees, employees, and superiors has an important role to play in ensuring good relations among the population in the work environment, then honest and consistent communication is also an important management tool in employee engagement. (Durkin et al., 2007) states that if communication is not carried out consistently and honestly, it can cause employees to start thinking about the future of the company and the desire to leave the company. Employees admit that communication is an indication of their sense of the company (Faisal Aman, S Hossein Cheraghi, Krishna K Krishnan, 2013). The importance of employee communication in various organizations was proven when a survey by The Chartered Institute of Personel and Development (CIPD) reported that the two things that most influenced employee engagement were having the opportunity to interact upward and always having good information about what was happening to the organization (Andrew C Ologbo \& Saudah Sofian, 2013).

Hypothesis 2: There is a significant positive effect between Employee Communication and Employee Engagement.

\subsection{Relationship between Rewards and Recognition and Employee Engagement}

Oktafien \& Bayyinah, (2017) states that an organization must have a good payroll system that can motivate employees to work within the company. This includes certainty of benefits and compensation, recognition such as an award (award), service marks, and others. The reward system also plays a very important role in employee engagement where staff will feel valued for their skills, knowledge, and contributions to the organization (Mukherjee et al., 2009). After doing a good job, employees are not necessarily satisfied with the results of their work, but the company's recognition of the work that has been done is highly expected by employees. Although in general companies often provide formal wages and recognition or appreciation programs in return for employee contributions and ideas, many employees still expect appreciation or recognition per day (A. S. Hoffman, 2012).

Hypothesis 3: There is a significant positive effect between Reward and Recognition and Employee Engagement.

\subsection{Relationship between Leadership and Employee Engagement}

Leadership has been recognized as an important component in the effectiveness of employee or workforce management (Liu et al., 2003). Leadership is also known as one of the major elements that affect employee perceptions in the work environment and workforce engagement (Boerner et al., 2007) (Macey \& Schneider, 2008). Previous research by Wildermuth et al., (2008) and Storey et al., (2008) shows that engagement occurs naturally when a leader inspires. Khuong \& Yen, (2014) in their research discussed the influence of leadership style and employee engagement. The results of the study suggest that leadership has a positive influence on employee management, which is also supported by previous research (Ekowati et al., 2013).

Hypothesis 4: There is a significant positive influence between Leadership and Employee Engagement.

\subsection{The relationship between Work-Life Balance and Employee Engagement}

Several studies have stated that there is a direct relationship between the application of work-life balance, where this will ultimately relate to the work-life balance of employees and employee engagement. The relationship between the application of work-life balance and employee engagement can be explained using social exchange theory (MOrris \& AU - Douglass, 2014). This theory explains companies that care and provide opportunities for their employees, so employees will show certain attitudes and behaviors. More specifically, when employees receive the favorable treatment they tend to reciprocate, which leads to profits between the company and the employees (Rhoades \& Eisenberger, 2002). The application of social exchange theory to work-life balance is when employees feel that the company helps balance work and personal life, so employees feel cared for and supported by the company. Adhering to the norm of reciprocity, it is said that employees feel obliged to reciprocate the things that the company provides by providing better attitudes and behaviors at work. Employees respond to these things by increasing positive feelings about work (Hari Srinivas, 2005). When employees are given attention by the company, employees will respond with a certain level of engagement (Saks, 2006).

Hypothesis 5: There is a significant positive effect between Work-Life Balance and Employee Engagement. 


\subsection{Relationship between Employee Engagement and Organizational Citizenship Behavior (OCB)}

Jagannathan \& Anitha, (2014) in her research states that employee engagement is the level where the commitment and involvement of an employee have on the company and the value of the organization. Based on several previous studies, employee engagement is influenced by several factors including emotional and rational which are related to work and overall work experience (Bakker et al., 2012); (Karatepe et al., 2010) and (Hayuningtyas \& Helmi, 2016) suggests that a high level of employee engagement increases performance. , tigas performance, and $\mathrm{OCB}$, productivity, independence, affective commitment, commitment, psychological climate levels, and customer service.

Hypothesis 6: There is a significant positive effect between Employee Engagement and Organizational Citizenship Behavior (OCB).

\subsection{Relationship between Employee Development and Organizational Citizenship Behavior (OCB) with Employee Engagement as an Intervening Variable}

Andrew C Ologbo \& Saudah Sofian, (2013) in their research on individual factors and work results from employee engagement resulted that employee engagement became a variable that mediates the relationship between individual factors including employee development, employee communication, and co-employee support and work outcomes include job satisfaction, organizational commitment. , intention to quit, and OCB. (Nikolett \& Christina Nawangsarit, 2019) in his research examined the influence of Human Resources Management (HRM) Practice consisting of employee participants, compensation and benefits, reward systems, career planning, training and development, and employee empowerment on employee engagement and OCB which had a significant positive effect on both that variable.

Hypothesis 7: There is a significant positive effect between Employee Development and Organizational Citizenship Behavior (OCB) with Employee Employee as an intervening variable.

\subsection{Relationship between Employee Communication and Organizational Citizenship Behavior (OCB) with Employee Engagement as an Intervening Variable}

Andrew C Ologbo \& Saudah Sofian, (2013)in their research stated that employee engagement is a variable that mediates between individual factors, one of which is employee communication and OCB.

Hypothesis 8: There is a significant positive effect between Employee Communicative and Organizational Citizenship Behavior (OCB) with Employee Engagement as an intervening variable.

\subsection{Relationship of Reward and Recognition and Organizational Citizenship Behavior (OCB) with Employee Engagement as an Intervening Variable}

Saks, (2006) in his research found that partially mediating the relationship between antecedent includes job characteristics, perceived organizational support, perceived supervisor support, reward and recognition, procedural justice, distributive justice, and consequence including job satisfaction, organization commitment, intent to quit, OCB. Reward and recognition have a fairly close relationship with OCB. Not only does reward and recognition affect OCB but several studies have also stated the opposite. Veverapa's research also states that the presence of OCB in employees has an impact on rewards such as promotions given by the company to employees (Noviardila et al., 2020). Podsakoff et al., (2009) in their research resulted in a positive relationship between OCB and employee reward allocation decisions.

Hypothesis 9: There is a significant positive effect between Reward and Recognition and Organizational Citizenship Behavior (OCB) with Employee Engagement as an intervening variable.

\subsection{Relationship between Leadership and Organizational Citizenship Behavior (OCB) with Employee Engagement as an Intervening Variable}

Modul et al., (2019), Chen \& Hung, (2016) in his research using the AMOS Structural Equation Modeling (SEM) program in conducting a mediation test resulted that employee engagement did not mediate the relationship between leaders and OCB. However, this research shows that leadership directly has a significant positive effect on OCB in being tested separately or simultaneously with employee engagement as mediation. In Organ's research (1997) states that in addition to mood traits, organization and leadership predict OCB at the altruism and compliance levels.

Hypothesis 10: There is a significant positive effect between Leadership and Organizational Citizenship Behavior (OCB) with Employee Engagement as an intervening variable. 


\subsection{Relationship between Work-Life Balance and Organizational Citizenship Behavior (OCB) with Employee Engagement as an Intervening Variable}

Some researchers state that the work-life balance that increases significantly contributes to increasing the OCB of employees in the organization (Harikaran \& Thevanes, 2018), (Ambert et al., 2000) Researchers also argue that work-life balance has become an important issue because it tends to have positive impacts such as mental health and resilience, higher productivity and effectiveness, higher levels of job satisfaction and involvement, lower turnover intentions, reduced absenteeism, increased performance in roles, organizational commitment, employee morale, increase employee sense of competence, reduce employee stress, employee loyalty (Ambert et al., 2000); (Chan et al., 2017); (Podsakoff et al., 2009) and (L et al., n.d.) show that work-life balance exists to increase employee engagement in OCB which will have a positive impact. However, employees with the conflicting job and family demands may not always be able to perform optimally and exhibit the high OCB levels expected by the organization (Harikaran \& Thevanes, 2018). In other words, increasing work-life balance contributes to encouraging OCB of employees in the organization by creating a positive work environment. However, few studies have considered the relationship between work-life balance and OCB in the past. Thus, this review exists as a gap in the literature and wishes to establish a positive relationship between work-life balance and employee OCB. Based on the literature evidence cited, it is possible to establish a positive relationship between work-life balance and OCB. According to literature, this review establishes that work-life balance has a positive relationship with employee OCB.

Hypothesis 11: There is a significant positive effect between Work-Life Balance and Organizational Citizenship Behavior (OCB) with Employee Engagement as an intervening variable.

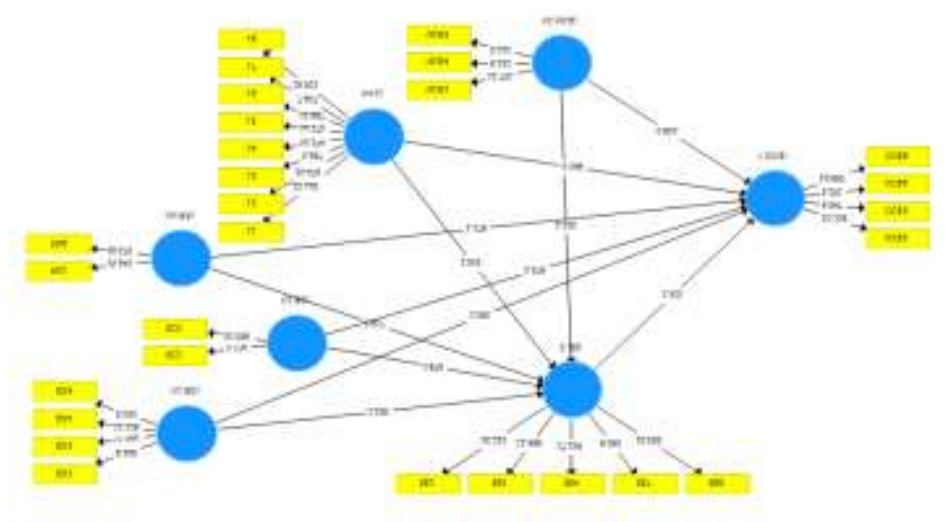

Figure 1. Research Model

\section{Research Method}

The population that becoming the unit of analysis in this research is store managers of Starbucks Surabaya, Indonesia. This study use employee engagement as an intervening variable. The main instrument in collecting data in this study is to provide a structured questionnaire adapted from various previous studies that are considered to have been tested for reliability and validity. Data analysis techniques in this study using the structural equation model (SEM) with the help of software SmartPLS 3.

\section{Result}

\subsection{Outer Model}

Table 1. Cronbach's Alpha, Composite Reliability, and AVE

\begin{tabular}{llll}
\hline & $\begin{array}{l}\text { Cronbach's } \\
\text { Alpha }\end{array}$ & $\begin{array}{l}\text { Composite } \\
\text { Reliability }\end{array}$ & $\begin{array}{l}\text { Average } \\
\text { Variance } \\
\text { Extracted }(A V E)\end{array}$ \\
\hline X1 (ED) & 0.854 & 0.900 & 0.693 \\
X2 (EC) & 0.751 & 0.888 & 0.799 \\
X3 (RR) & 0.766 & 0.894 & 0.809 \\
X4 (L) & 0.931 & 0.943 & 0.677 \\
X5 (WLB) & 0.726 & 0.832 & 0.623 \\
Y (OCB) & 0.804 & 0.872 & 0.630 \\
Z (EE) & 0.880 & 0.912 & 0.675 \\
\hline
\end{tabular}


Based on table 1, it can be seen that all constructs have met the criteria for being reliable. This is indicated by the Composite Reliability value above 0.70 and AVE above 0.50 .

\subsection{Inner Model}

Table 1. R-square and R-square Adjusted

\begin{tabular}{ccc}
\hline & R-square & R-square Adjusted \\
\hline $\mathrm{Y}(\mathrm{OCB})$ & $0.547(54.7 \%)$ & $0.429(42.9 \%)$ \\
$\mathrm{Z}(\mathrm{EE})$ & $0.715(71.5 \%)$ & $0.656(65.6 \%)$ \\
\hline
\end{tabular}

These results indicate that the Organizational Citizenship Behavior (Y) variable can be influenced by Employee Development (X1), Employee Communication (X2), Reward and Recognition (X3), Leadership (X4), and Work-Life Balance (X5) of 4.29\% and the rest influenced by other factors, while the Employee Engagement (Z) variable can be influenced by Employee Development (X1), Employee Communication (X2), Reward and Recognition (X3), Leadership (X4), and Work-Life Balance (X5) of 65.6\%. other factors that were not examined in this study.

Then the increase in value indicated by the difference in the acquisition of the two variables above shows that employee engagement as an intervening variable has sufficient influence on the organizational citizenship behavior variable, although not in large numbers.

\subsection{Testing Hypothesis}

Table 2. Summary of Hypothesis Test Result

\begin{tabular}{|c|c|c|c|c|c|}
\hline \multicolumn{6}{|c|}{ Indirect Influence } \\
\hline $\begin{array}{c}\text { Path } \\
\text { Coefficient }\end{array}$ & $\begin{array}{c}\text { Original } \\
\text { Sample }(\mathrm{O})\end{array}$ & $\begin{array}{l}\text { Sample Mean } \\
\text { (M) }\end{array}$ & $\begin{array}{c}\text { Standar } \\
\text { Deviation } \\
(\text { STDEV) }\end{array}$ & $\begin{array}{c}\text { T-Statistics } \\
(|\mathrm{O} / \mathrm{STDEV}|)\end{array}$ & P-Value \\
\hline $\begin{array}{l}\mathrm{X} 1(\mathrm{ED}) \rightarrow \mathrm{Z} \\
(\mathrm{EE}) \rightarrow \mathrm{Y} \\
\quad(\mathrm{OCB})\end{array}$ & 0.022 & 0.049 & 0.111 & 0.194 & 0.846 \\
\hline $\begin{array}{l}X 2(E C) \rightarrow Z \\
(E E) \rightarrow Y \\
(\mathrm{OCB})\end{array}$ & 0.075 & 0.056 & 0.111 & 0.677 & 0.499 \\
\hline $\begin{array}{l}X 3(\mathrm{RR}) \rightarrow \mathrm{Z} \\
(\mathrm{EE}) \rightarrow \mathrm{Y} \\
(\mathrm{OCB})\end{array}$ & -0.053 & -0.033 & 0.095 & 0.588 & 0.577 \\
\hline $\begin{array}{l}\mathrm{X} 4(\mathrm{~L}) \rightarrow \mathrm{Z} \\
(\mathrm{EE}) \rightarrow \mathrm{Y} \\
\quad(\mathrm{OCB})\end{array}$ & 0.239 & 0.205 & 0.207 & 1.155 & 0.249 \\
\hline $\begin{array}{l}X 5(\mathrm{WLB}) \rightarrow \\
\mathrm{Z}(\mathrm{EE}) \rightarrow \mathrm{Y} \\
(\mathrm{OCB})\end{array}$ & 0.176 & 0.155 & 0.136 & 1.300 & 0.194 \\
\hline \multicolumn{6}{|c|}{ Direct Influence } \\
\hline Path Coefficient & $\begin{array}{l}\text { Original Sample } \\
\text { (O) }\end{array}$ & $\begin{array}{l}\text { Sample Mean } \\
\text { (M) }\end{array}$ & $\begin{array}{c}\text { Standard } \\
\text { Deviation } \\
(\text { STDEV })\end{array}$ & $\begin{array}{c}\text { T-Statistics } \\
(|\mathrm{O} / \mathrm{STDEV}|)\end{array}$ & P-Value \\
\hline $\begin{array}{l}\mathrm{X} 1(\mathrm{ED}) \rightarrow \mathrm{Z} \\
(\mathrm{EE})\end{array}$ & 0.050 & 0.047 & 0.218 & 0.228 & 0.819 \\
\hline $\begin{array}{l}\mathrm{X} 2 \underset{(\mathrm{EC})}{(\mathrm{EE})} \rightarrow \mathrm{Z} \\
\end{array}$ & 0.173 & 0.181 & 0.197 & 0.881 & 0.379 \\
\hline $\begin{array}{l}\mathrm{X} 3 \underset{(\mathrm{RR})}{(\mathrm{EE})} \rightarrow \mathrm{Z} \\
\end{array}$ & 0.312 & 0.208 & 0.261 & 1.194 & 0.233 \\
\hline $\begin{array}{l}\mathrm{X} 4 \underset{(\mathrm{L}) \rightarrow \mathrm{Z}}{(\mathrm{EE})} \\
\text { ( }\end{array}$ & 0.551 & 0.543 & 0.263 & 2.097 & 0.037 \\
\hline $\begin{array}{c}\mathrm{X} 5(\mathrm{WLB}) \\
(\mathrm{EE})\end{array}$ & 0.406 & 0.405 & 0.126 & 3.230 & 0.001 \\
\hline $\begin{array}{l}\mathrm{Z}(\mathrm{EE}) \rightarrow \mathrm{Y} \\
\quad(\mathrm{OCB})\end{array}$ & 0.434 & 0.411 & 0.307 & 1.414 & 0.158 \\
\hline
\end{tabular}




\subsection{Direct effects}

The results of data processing show that the first hypothesis is rejected because the t-statistic value is $0.228<\mathrm{t}$-statistic and the p-value are $0.05>0.819$. The results of this study indicate that employee development has no positive effect on employee engagement at Starbucks managers.

The results of data processing show that the first hypothesis is rejected because the t-statistic value is $0.881<\mathrm{t}$-statistic and the p-value are 0.05> 0.374. The results of this study indicate that employee communication has no positive effect on employee engagement at Starbucks managers.

The results of data processing show that the first hypothesis is rejected because the t-statistic value is $1.194<\mathrm{t}$-statistic and the p-value are 0.05>0.233. The results of this study indicate that reward and recognition has no positive effect on employee engagement at Starbucks managers.

The results of data processing show that the first hypothesis is rejected because the t-statistic value is $2.097<\mathrm{t}$-statistic and the p-value are 0.05>0.037. The results of this study indicate that leadership has no positive effect on employee engagement in Starbucks managers.

The results of data processing show that the first hypothesis is accepted because the t-statistic value is $3.230<\mathrm{t}$-statistic and the p-value are 0.05>0.001. The results of this study indicate that work-life balance has a positive effect on employee engagement at Starbucks managers.

The results of data processing show that the first hypothesis is rejected because the t-statistic value is $1.414<\mathrm{t}$-statistic and the p-value $0.05>0.158$ is rejected. The results of this study indicate that employee engagement has no positive effect on OCB in Starbucks managers.

\subsection{Indirect Effects}

Based on the results of the analysis conducted by SmartPLS as in table 3, it can be concluded that the variables Employee Development (X1), Employee Communication (X2), Reward and Recognition (X3), and Leadership (X4), have no indirect effect on Organizational Citizenship Behavior (Y ) through Employee Engagement $(\mathrm{Z})$. The results show that the t-statistic is smaller than the t-table and the p-value is greater than 0.5 , which means that the employee engagement variable as an intervening in the study is less able to mediate so that it cannot strengthen the effect of OCB, which is the dependent variable.

However, the work-life balance (X5) variable has an indirect effect on OCB. The results show that the $t-$ statistic is greater than the t-table and the $\mathrm{p}$-value is smaller than 0.05 , this means that the employee engagement variable as an intervening variable has succeeded in influencing OCB, which is the dependent variable.

The inability of employee management to be a mediator variable in this study is quite reasonable if we look back at table 2 which shows the R-square results where the test results for OCB (Y) only have an effect of $42.9 \%$ while the rest is influenced by other factors not discussed in the study. this. This small percentage can be the reason why employee engagement is less able to be a mediator to increase the influence of employee development, employee communication, reward and recognition, leadership, and work-life balance on OCB. Then the objects in this study are employees with a service period of more than 2 years who have a position as manager.

\section{Discussion And Practical Implications 5.1 Direct Effects}

The results of data processing indicate that employee development, employee communication, reward and recognition, and leadership have no positive effect on employee engagement in Starbucks managers.

The results of data processing show that work-life balance has a positive effect on employee engagement at Starbucks managers.

The results of data processing show that employee engagement has no positive effect on OCB in Starbucks managers.

\subsection{Indirect Effects}

Based on the results of the analysis, it can be concluded that the variables Employee Development (X1), Employee Communication (X2), Reward and Recognition (X3), and Leadership (X4) have no indirect effect on Organizational Citizenship Behavior (Y) through Employee Engagement (Z). The results show that the tstatistic is smaller than the t-table and the p-value is greater than 0.5 , which means that the employee engagement variable as an intervening in the study is less able to mediate so that it cannot strengthen the effect of OCB, which is the dependent variable.

However, the work-life balance (X5) variable has an indirect effect on OCB. The results show that the tstatistic is greater than the t-table and the p-value is smaller than 0.05 , this means that the employee engagement variable as an intervening variable has succeeded in influencing OCB, which is the dependent variable.

Considering that the research results show that reward and recognition do not have a significant effect on employee engagement or OCB, Starbucks should think more about other ways that are expected to increase the involvement of managers in the company. 
For further research, it is necessary to develop and use more variables and involve respondents with a wider scope in researching so that it can produce far better research results.

\section{References}

Ambert, Douglas, Cooper, \& Martha. (2000). Issues in Supply Chain Management. Industrial Marketing Management, 29. https://doi.org/10.1016/S0019-8501(99)00113-3

Andrew C Ologbo, \& Saudah Sofian. (2013). Individual and organizational factors of employee engagement on employee work outcomes. International Journal of Business and Behavioral Sciences, 498-502.

Bakker, A. B., Tims, M., \& Derks, D. (2012). Proactive personality and job performance: The role of job crafting and work engagement. Human Relations, 65(10), 1359-1378. https://doi.org/10.1177/0018726712453471

Boerner, S., Eisenbeiss, S. A., \& Griesser, D. (2007). Follower Behavior and Organizational Performance: The Impact of Transformational Leaders. Journal of Leadership \& Organizational Studies, 13(3), 15-26. https://doi.org/10.1177/10717919070130030201

Chan, W., Zhang, Y., Le, Q. V., \& Jaitly, N. (2017). Latent sequence decompositions. 5th International Conference on Learning Representations, ICLR 2017 - Conference Track Proceedings, 1-12.

Chen, L., \& Hung, H.-C. (2016). The indirect effect in multiple mediators model by structural equation modeling. European Journal of Business, Economics and Accountancy, 4(3), 36-43.

Durkin, Kevin, Conti-Ramsden, \& Gina. (2007). No TitleLanguage, Social Behavior, and the Quality of Friendships in Adolescents With and Without a History of Specific Language Impairment. Child Development, 78. https://doi.org/10.1111/j.1467-8624.2007.01076.x

Ekowati, V. M., Troena, E. A., \& Noermijati, N. (2013). Organizational Citizenship Behavior Role in Mediating the Effect of Transformational Leadership, Job Satisfaction on Employee Performance: Studies in PT Bank Syariah Mandiri Malang East Java. International Journal of Business and Management, 8(17), 1-12. https://doi.org/10.5539/ijbm.v8n17p1

Faisal Aman, S Hossein Cheraghi, Krishna K Krishnan, H. L. (2013). Study of the impact of riveting sequence, rivet pitch, and gap between sheets on the quality of riveted lap joints using finite element method. The International Journal of Advanced Manufacturing Technology, 67(1), 545-562.

Hari Srinivas. (2005). Defining squatter settlements. Global Development Research Center Web Site, Www. Gdrc. Org/Uem/Define-Squatter. Html, Viewed, 9.

Harikaran, S., \& Thevanes, N. (2018). The Relationships among Work-Life Balance , Organizational Citizenship Behavior and Organizational Performance : A Review of Literature. IOSR Journal of Business and Management (IOSR-JMB), 20(8), 25-31. https://doi.org/10.9790/487X-2008052531

Hayuningtyas, D. R. I., \& Helmi, A. F. (2016). Peran Kepemimpinan Otentik terhadap Work Engagement Dosen dengan Efikasi Diri sebagai Mediator. Jurnal Psikologi UGM, 1(3), 167-179. https://doi.org/10.22146/gamajop.8814

Hoffman, A. S. (2012). Hydrogels for biomedical applications. Advanced Drug Delivery Reviews, 64(SUPPL.), 18-23. https://doi.org/10.1016/j.addr.2012.09.010

Hoffman, C., \& Paradise, J. (2008). Health insurance and access to health care in the United States. Annals of the New York Academy of Sciences, 1136, 149-160. https://doi.org/10.1196/annals.1425.007

J., A. (2014). Determinants of employee engagement and their impact on employee performance. International Journal of Productivity and Performance Management, 63(3), 308-323. https://doi.org/10.1108/IJPPM-012013-0008

Jagannathan, \& Anitha. (2014). Determinants of employee engagement and their impact on employee performance. International Journal of Productivity and Performance Management, 63. https://doi.org/10.1108/IJPPM-01-2013-0008

Karatepe, Osman, \& Tuna. (2010). Role Stress, Emotional Exhaustion, and Turnover Intentions: Does Organizational Tenure in Hotels Matter? Journal of Human Resources in Hospitality \& Tourism, 9. https://doi.org/10.1080/15332840903323364

Khuong, M. N., \& Yen, N. H. (2014). The effects of leadership styles and sociability trait emotional intelligence on employee engagement - A study in Binh Duong City, Vietnam. International Journal of Current Research and Academic Review, 2(1), 121-136.

Kumar, D. P., \& Swetha, G. (2011). A Prognostic Examination of Employee Engagement. International Journal of Trade, Economics and Finance, 2(3).

L, D., Mackenzie, D.nichols, J., Royle, J. andre., Kenneth, Poolock, L.bailey, L., \& E.hines, J. (n.d.). occupancy estimation and modeling inferring patterns and dynamics of species occurrence. Academic Press.

Liu, W., Lepak, D. P., Takeuchi, R., \& Sims, H. P. (2003). Matching leadership styles with employment modes: Strategic HRM perspective. Human Resource Management Review, 13(1), 127-152. https://s3.amazonaws.com/academia.edu.documents/38191333/leadershipandmodeHRMR2003.pdf?respons 
e-content-disposition=inline\%3B filename\%3DMatching_Leadership_Styles_with_Employme.pdf\&XAmz-Algorithm=AWS4-HMAC-SHA256\&X-Amz-Credential=AKIAIWOWYYGZ2Y53UL3A\%2F

Macey, W. H., \& Schneider, B. (2008). The Meaning of Employee Engagement.: EBSCOhost. 1, 3-30. http://web.b.ebscohost.com.esc-web.lib.cbs.dk/ehost/pdfviewer/pdfviewer?sid=93c9a7d9-10bb-4006-9258ae22a70ef662@sessionmgr110\&vid=1\&hid=123

Modul, P., Berbentuk, P., Smash, P., \& Materi, B. (2019). Pengembangan Modul Pembelajaran Berbentuk PopUp dan Smash Book Materi Sifat Cahaya Bagi Siswa Penyandang Disabilitas Rungu. UPEJ Unnes Physics Education Journal, 8(1), 8-15. https://doi.org/10.15294/upej.v8i1.29497

Mone, Edward, London, \& Manuel. (2018). Employee Engagement Through Effective Performance Management: A Practical Guide for Managers. https://doi.org/10.4324/9781315626529

MOrris, S., \& AU - Douglass, C. (2014). Douglass, C. \& Morris, S.R. (2014). Student perspectives on selfdirected learning and assessment. Journal of the Scholarship of Teaching and Learning, 14 (1), 13-25. Ournal of the Scholarship of Teaching and Learning, 14.

Mukherjee, A., Bhattacharya, P., Shi, F., Fryar, A. E., Mukherjee, A. B., Xie, Z. M., Jacks, G., \& Bundschuh, J. (2009). Chemical evolution in the high arsenic groundwater of the Huhhot basin (Inner Mongolia, PR China) and its difference from the western Bengal basin (India). Applied Geochemistry, 24(10), 1835-1851. https://doi.org/10.1016/j.apgeochem.2009.06.005

Muthuveloo, R., Shanmugam, N., \& Teoh, A. P. (2017). The impact of tacit knowledge management on organizational performance: Evidence from Malaysia. Asia Pacific Management Review, 22(4), 192-201. https://doi.org/10.1016/j.apmrv.2017.07.010

Nikolett, V., \& Christina Nawangsarit, L. (2019). Impact of Human Resource Management Practices: Factors Influencing Organizational Citizenship Behaviour at Kelapa Gading Mall. International Journal of Scientific and Research Publications (IJSRP), 9(2), p8628. https://doi.org/10.29322/ijsrp.9.02.2019.p8628

Noviardila, I., Inquiry, P. G., Miranto, S., Chandra, A. A., Yensy, N. A., Nana, S., Arsidi, Hidayah, N., Unnes, E., Nurainun, O., Rasyimah, H., Studi, P., Guru, P., Dasar, S., Keguruan, F., Ilmu, D. A. N., Dahlan, U. A., Pgri, U., Buana, A., ... Ismah, I. (2020). 済無No Title No Title. Journal of Chemical Information and Modeling.

Oktafien, S., \& Bayyinah, N. (2017). SISTEM PENGENDALIAN INTERNAL PENGGAJIAN TERHADAP PRODUKTIVITAS KERJA KARYAWAN (STUDI PADA PT MANDALA MULTIFINANCE, Tbk .... Jurnal Manajemen Dan Bisnis .., https://ejournal.unisba.ac.id/index.php/performa/article/view/2642

Podsakoff, N. P., Whiting, S. W., Podsakoff, P. M., \& Blume, B. D. (2009). Individual- and OrganizationalLevel Consequences of Organizational Citizenship Behaviors: A Meta-Analysis. Journal of Applied Psychology, 94(1), 122-141. https://doi.org/10.1037/a0013079

Rhoades, L., \& Eisenberger, R. (2002). Perceived organizational support: A review of the literature. Journal of Applied Psychology, 87(4), 698-714. https://doi.org/10.1037/0021-9010.87.4.698

Saks, A. M. (2006). Antecedents and consequences of employee engagement. Journal of Managerial Psychology, 21(7), 600-619. https://doi.org/10.1108/02683940610690169

Stephen P. Robbins, Tim Judge, Bruce Millett, M. B. (2014). Organisational Behaviour Always learning.

Storey, J., Ulrich, D., Welbourne, T. M., \& Wright, P. M. (2008). Employee engagement. The Routledge Companion to Strategic Human Resource Management, 299-315. https://doi.org/10.4324/978020388901529

Wildermuth, Cris, Pauken, \& Patrick. (2008). A perfect match: Decoding employee engagement - Part II: Engaging jobs and individuals. Industrial and Commercial Training, 40. https://doi.org/10.1108/00197850810876253 